Published in Strategic Management Journal 31(2), 224-236

\title{
INNOVATION OBJECTIVES, KNOWLEDGE SOURCES, AND THE BENEFITS OF BREADTH
}

\author{
Aija Leiponen \\ Department of Applied Economics and Management \\ 251 Warren Hall \\ Cornell University \\ Ithaca, NY 14853-7801 \\ Constance E. Helfat \\ Tuck School of Business at Dartmouth \\ 100 Tuck Hall \\ Hanover, NH 03755
}

Keywords: innovation, knowledge sources, innovation objectives, managerial cognition, parallel search

This paper benefited from presentations at the Academy of Management annual meeting, Boston University, Carnegie Mellon, Cornell, Dartmouth, Informs College of Organizations meeting, INSEAD, New York University, and the University of Illinois, and the comments of Bob Hansen, Joe Mahoney, Steve Michael, Jim Utterback, as well as Rich Bettis and two anonymous reviewers. The usual caveat applies. 


\begin{abstract}
Given the inherent risk of innovative activity, firms can improve the odds of success by pursuing multiple parallel objectives. Since innovation draws on many sources of ideas, firms also may improve their odds of successful innovation by accessing a large number of knowledge sources. In this study, we conduct one of the first firm-level statistical analyses of the impact on innovation of breadth in both innovation objectives and knowledge sources. The empirical results suggest that broader horizons with respect to innovation objectives and knowledge sources are associated with successful innovation. We do not find diminishing returns to breadth in innovation objectives, which suggests that firms may tend to search too narrowly. We interpret these results in light of well-known cognitive biases towards searching in relatively familiar domains.
\end{abstract}




\section{INTRODUCTION}

Innovation is a risky business. Under conditions of high uncertainty, it makes sense to ask: how can firms maximize their chances of success? In the context of innovation activity, there is a long-standing answer: "safety would seem to lie in numbers and variety of attack" (Jewkes, Sawers, and Stillerman, 1958, p. 184). In other words, search broadly.

Prior research has shown that while firms often search narrowly for knowledge within their current technological domains (Helfat, 1994), greater innovation success occurs when firms search more broadly for knowledge in a variety of technological domains and geographic locations (Ahuja and Lampert, 2001; Ahuja and Katila, 2004; Katila and Ahuja, 2002). In addition, breadth in the types of information sources that firms utilize, such as knowledge from customers (von Hippel, 1996) and suppliers (Leiponen, 2000, 2002), is likely to affect innovation outcomes (Rosenkopf and Nerkar, 2001; Ahuja and Katila, 2001; Laursen and Salter, 2006; Veugelers and Cassiman, 1999).

In addition to search for new sources and types of knowledge, the direction and breadth of technological search depends importantly on firms' R\&D objectives. Empirical research on innovation at the firm level has yet to incorporate the role of objectives. Here we conduct one of the first firm-level statistical analyses of the impact on technological innovation of breadth in both innovation objectives and knowledge sources. The empirical results suggest that broader horizons with respect to innovation objectives and knowledge sources are associated with successful innovation.

\section{INNOVATION OBJECTIVES AND KNOWLEDGE SOURCES}

Studies of innovation activity often distinguish between product and process innovation. Within these types of general innovation activities, firms also are likely to have specific objectives. Product objectives may include goals such as the development of a completely new product or the improvement of an existing product. Process objectives may include goals such as reduction of labor costs or improved manufacturing flexibility. Cohen and Malerba (2001) 
have used the term "technical goals" to refer to these more specific types of innovation objectives, which are the focus of this study.

In their innovation activities, firms also may seek information from a variety of sources. The Yale (Klevorick et. al, 1995) and PACE (Arundel, Van de Paal, and Soete, 1995) surveys in the U.S. and Europe, respectively, have documented the wide range of knowledge sources used in innovation at the industry level. The knowledge sources in these surveys include the firm's own industrial R\&D, other firms in the same industry, customers, suppliers, university research, government research laboratories and agencies, and professional and technical societies. Similarly, our analysis focuses on types of knowledge sources that are connected to different parts of the value chain or activity system.

\section{BENEFITS OF BREADTH IN INNOVATION SEARCH}

Early research argued that because the likelihood of innovation success is highly uncertain, firms could improve the odds of innovation success by using what Nelson (1961) termed a "parallel-path strategy" of utilizing a variety of different approaches in innovation activity. More recently, Baldwin and Clark $(2000,2003)$ have emphasized the benefits for innovation of conducting "multiple parallel searches."

A few mathematical models have analyzed a parallel path approach to innovation (Nelson, 1961; Evenson and Kislev, 1976; Baldwin and Clark, 2003). In these "sampling" models, the potential for innovation, or technological opportunity, is characterized as a distribution of values of innovation outcomes. When a firm undertakes innovation activity, it does not know ahead of time which innovation outcome it will draw from the distribution.

The sampling models apply to innovation objectives in the following manner. ${ }^{1}$ A decision maker faces uncertainty about the ultimate payoff when deciding whether to pursue a particular

\footnotetext{
${ }^{1}$ These models analyze projects rather than objectives or sources and are more complex than the analysis here, in that they include multiple "trials" with more than one set of draws from a distribution. A more detailed explanation of the translation from the formal models to the arguments presented here is available on request from the authors.
} 
objective. The payoff to innovation is increasing in the number of objectives, because the likelihood of obtaining a favorable draw (a fruitful objective) from a distribution of payoffs increases as the number of draws increases. In this context, a favorable draw is one that exceeds a critical value above which it is profitable to commercialize an innovation. The greater the number of draws from the distribution, the more likely it is that one of the draws will exceed the critical value needed for commercialization. As a result, pursing a greater number of objectives increases the probability that at least one of them will have a valuable innovation outcome.

Similar logic applies to knowledge sources. Under conditions of uncertainty regarding the payoff to individual knowledge sources, the likelihood of obtaining a favorable draw from a distribution of payoffs increases as the number of draws (knowledge sources) increases. By accessing a greater number of knowledge sources, the firm improves the probability of obtaining knowledge that will lead to a valuable innovation outcome.

The sampling models deal with statistical uncertainty of innovation outcomes; they do not consider cognitive processes that also affect innovation search. Prahalad and Bettis (1986) and Bettis and Prahalad (1995) point out that strategic choices are influenced by a "dominant logic" that makes it difficult for firms to manage strategic change. Gavetti and Levinthal (2000) further argue that cognition "seeds and constrains" search for new alternatives in a manner that makes distant search less likely. In addition, specific cognitive biases affect managerial decision making. For example, the availability heuristic (Tversky and Kahneman, 1973), whereby people rely on information that is easily retrieved, will cause managers to rely on information with which they are most familiar (Prahalad and Bettis, 1986). In addition, the adjustment and anchoring heuristic, whereby people make estimates by adjusting an initial value, creates a tendency toward "unwarranted optimism in the evaluation of the likelihood that a plan will succeed" (Tversky and Kahneman, 1974, p. 1130).

When applied to innovation, the adjustment and anchoring heuristic suggests that decision makers will underestimate the inherent uncertainty of innovation outcomes, and therefore will 
not search broadly enough. The availability heuristic, dominant logic, and cognitive constraints on search also suggest that firms are likely to search narrowly in forming innovation objectives and sourcing knowledge. In order to counteract these tendencies, the importance of breadth identified in the sampling models becomes even more salient.

An additional but unrelated reason to pursue breadth of knowledge sources has to do with combining complementary knowledge (Leiponen, 2005). Since innovation often results from knowledge recombination (see e.g., Kogut and Zander, 1992; Schumpeter, 1934), having a greater number of complementary sources of knowledge could improve innovation success.

The foregoing arguments suggest the following propositions:

\section{Proposition 1: Firms that have greater breadth of innovation objectives experience greater innovation success, all else equal.}

Proposition 2: Firms that have greater breadth of knowledge sources experience greater innovation success, all else equal.

Firms that apply a given set of knowledge sources to a larger number of innovation objectives also may be able to multiply the benefits of their knowledge sources without incurring additional costs of knowledge acquisition. We therefore investigate whether, conditional on Propositions 1 and 2, the interaction of breadth in objectives and breadth in sources is associated with greater innovation success.

\section{Limits to Breadth}

Firms may face a tradeoff between depth and breadth in their innovation objectives, because cumulative learning is important for R\&D (Cohen and Levinthal, 1990; Helfat, 1994; Nelson and Winter, 1982). In addition, the marginal cost of adding an innovation objective may increase as the number of innovation objectives increases. For example, the complexity of managing a larger variety of objectives may cause organizational and managerial costs to increase. Prahalad and Bettis (1986) further note that due to cognitive factors associated with a 
dominant logic, effective management requires constraints on the amount of strategic variety. Thus, breadth of innovation objectives may be subject to diminishing returns.

Breadth of knowledge sources also may be subject to diminishing marginal returns. Firms may encounter higher marginal costs due to increased complexity of managing both the variety of knowledge and the relationships needed to maintain access to these sources. In addition, the benefits of knowledge recombination from different sources may diminish as the number of sources increases. For example, using an NK model (Kauffman, 1993), Fleming and Sorenson (2001) show that it becomes increasingly difficult to combine technological components when the number of interactions among components grows.

Based on the foregoing arguments, we investigate whether, conditional on Propositions 1 and 2, innovation objectives and knowledge sources exhibit diminishing returns to breadth.

\section{DATA AND STATISTICAL INFERENCE}

The empirical setting in this study is the manufacturing sector in Finland. The data come from the Finnish R\&D Survey, the Finnish Community Innovation Survey (CIS), and the Finnish Employment Register. Statistics Finland, the national statistical agency, administered all of the surveys. The Community Innovation Survey was coordinated with the statistical agency of the European Union, Eurostat, which sponsors CIS surveys in several member countries. Eurostat coordinated the initial development of the survey instrument and the data collection techniques. ${ }^{2}$ The CEO or R\&D manager of each firm filled out the surveys.

The R\&D survey provides information on innovation success, including whether or not the firm introduced technological innovations and the percent of firm sales derived from the introduction of technologically new products. The CIS survey includes questions about R\&D

\footnotetext{
2 All manufacturing firms with more than 100 employees received the R\&D survey, as did a stratified random sample of firms with 10-99 employees. The sample for firms with fewer than 10 employees included only firms known to perform R\&D from earlier surveys or firms' public R\&D funding applications. For the CIS, Statistics Finland surveyed all Finnish manufacturing firms with more than 100 employees, as well as a random sample stratified by size and industry of the remainder of the manufacturing companies. 72 percent of the firms responded to the CIS survey.
} 
activity, innovation objectives, and knowledge sources related to innovation. Few data sets contain information on both innovation objectives and sources of knowledge for individual firms. Even many CIS surveys in other countries lack information on innovation objectives.

We combined the R\&D survey for the period 1996-1998, which contains the dependent variables in this study, with the CIS survey for the period 1994-1996, which contains most of the explanatory and control variables. The CIS survey for these years is the only one that contains usable data on innovation objectives. More recent Finnish CIS surveys dropped the questions regarding objectives. We then added education data for 1995 from the Finnish Employment Register in order to obtain additional control variables. The final sample consists of 339 firms that had data in both the R\&D and CIS surveys, and had some activity directed toward innovation. The sample is representative of the manufacturing sector in Finland and consists of 14 industries at the 2-digit level. Because the data are confidential, the firms are not identified by name. The sample includes separate observations for subsidiaries of larger companies, termed "business groups." As a result, the firms in the sample are not widely diversified.

The three surveys had a single respondent per firm, suggesting the need to check for common method variance. Since the variables come from three different surveys, and the same person is not likely to have filled out all forms, this reduces the potential for common method variance. Nevertheless, we checked for common method variance using Harmon's one-factor test (see Podsakoff and Organ, 1986). This analysis, described in the footnote below, suggests that our results are not subject to a common method bias in the survey responses. ${ }^{3}$

\footnotetext{
${ }^{3}$ We performed a factor analysis for each dependent variable and included all of the explanatory and control variables. The factor analyses without industry dummies retained 3 factors with eigenvalues greater than 1.00, and analyses including industry dummies retained 11 factors with eigenvalues greater than 1.00 . The first factor explained about 30 percent of the variance in each analysis. In the raw factor solution, breadth of objectives did not load most strongly on the same factor as the dependent variables, while breadth of sources did. In the varimax rotated factor solution, breadth of objectives and sources loaded on a different factor than did the dependent variables. These results suggest that common method variance is not a substantial problem.
} 
Our explanatory and control variables reflect data for 1994-96, and the dependent variables that measure innovation success reflect data for 1998 (a sales variable) and 1996-1998 (a binary variable). The time periods over which the dependent and right-hand side variables are measured have minimal overlap, thus alleviating simultaneity issues. Moreover, the relatively short time lag between innovation outcomes and prior objectives and sources is appropriate for the types of applied and developmental innovations that tend to occur in the industries in our sample.

The use of cross-sectional data poses the concern that firm characteristics that are correlated with objectives and sources could affect innovation success. To mitigate this concern, the analysis includes variables that control for important firm characteristics of this type. In particular, we control for R\&D spending and innovative capability, which are likely to have a large impact on innovation success and may be correlated with innovation objectives and sources. Because the data on objectives are available for only one time period, we are unable to utilize fixed effects estimation to further control for unobserved firm heterogeneity.

\section{VARIABLES}

\section{Dependent Variables}

To measure innovation success, we utilize two variables from the R\&D survey. The first is a binary $(0,1)$ variable, indicating whether the firm introduced any technological innovations (product as well as process) during 1996-1998. These innovations were new to the firm, and may or may not have been new to the market. The second variable is the percent of total firm sales revenues in 1998 that derived from the sale of technologically new products introduced during 1996-98. Of the firms that succeeded in innovating, approximately 92 percent introduced product innovations. Since 65 percent of the innovating firms had process innovations, however, product sales do not fully reflect innovation success. By using both the binary innovation and product sales variables, we obtain a fuller picture of innovation success. 
We use probit maximum likelihood estimation for the binary indicator and tobit maximum likelihood estimation for the sales variable; the latter is censored because sales of new products can only be zero or positive. We use Limdep to estimate all of the models, except the model in Table 5 with an interaction effect that is estimated using Stata.

\section{Explanatory Variables}

The key explanatory variables in our study represent breadth of innovation objectives that firms pursued and breadth of knowledge sources that firms utilized in their innovation activities. The CIS survey asked respondents to identify the importance of each of 10 objectives, listed in table 1. In addition, the survey asked respondents to identify the importance of each of 12 sources of information used in innovation activities, also listed in table 1.

In order to account for the fact that some objectives and sources have greater importance than others, we adopted the approach introduced by Cohen and Malerba (2001) in their analysis of industry-level innovation activity. The survey asked firms to "evaluate the importance of the following objectives/sources of information for the innovation activities of your firm" on a Likert scale from zero (not important at all/not used) to three (very important). For each objective and knowledge source, we first assigned a binary value based on whether the survey response indicated that the item was important to the firm. A survey response of either two (important) or three (very important) received a binary value of one; survey responses of zero (not important at all/not used) or one (some importance) received a binary value of zero. The use of binary values helps to alleviate potential measurement error that might arise from use of a Likert scale (Cohen and Malerba, 2001), and alleviates the problem that an ordinal Likert scale cannot be interpreted as an interval scale. ${ }^{4}$

To construct a variable indicating breadth of important knowledge sources, we summed the binary values for the 12 sources. Other researchers such as Mol and Birkenshaw (2006) and

\footnotetext{
${ }^{4}$ Because respondents may have difficulty making fine-grained distinctions between very important and important sources, or between unimportant and not very important sources, this could result in measurement error.
} 
Laursen and Salter (2006) have adopted a very similar approach using UK CIS data. This variable has a maximum value of twelve. We constructed a similar variable for breadth of objectives by summing the binary values for the different objectives. This variable has a maximum value of ten. For the objectives in particular, it is possible that some may overlap; for example, expanding the product assortment could increase market share. If objectives in the survey overlap, a firm might have answered that it had multiple objectives when the firm actually had fewer underlying objectives. This possibility works against our finding a positive association between breadth of objectives and innovation success, because firms would have reported a greater number of objectives than they actually had. In addition, in the empirical analysis, we conduct a sensitivity test to account for possible overlap among objectives.

As shown in table 1, on average the most important innovation objectives were those to improve the quality of existing products and to enter new markets or increase share in existing markets, followed by objectives to replace outdated products, expand the product assortment, improve production flexibility, and reduce labor costs. The most important knowledge sources were the firm itself and its customers, followed by knowledge from competitors, other firms in the business group, and suppliers.

\section{Control Variables}

Logarithm of Number of Employees. Because larger firms have access to greater financial and human resources, these firms may have a greater ability to achieve at least a single innovation. Larger firms also may derive more sales from a single innovation, since these firms have a larger base of customers. We use the natural logarithmic transformation of the raw data.

Logarithm of R\&D Expenditures. Because firms explicitly direct R\&D spending toward the development of new products and processes, greater R\&D expenditures may increase the probability of, and revenues from, successful innovation. Moreover, firms that spend more in 
total on innovation activity may have the ability to fund greater breadth of innovation objectives. R\&D expenditures are also measured in natural logarithmic form.

Percent of Employees with Postgraduate Degrees; Percent of Employees with College Technical Degrees; Business Group Subsidiary. We control for firm innovative capability in two ways. First, employee skills and knowledge are critical inputs. We therefore include the percent of firm employees with postgraduate degrees (Ph.D. or licentiate) as a proxy for the research training of employees. We also include the percent of firm employees with college but not postgraduate degrees in engineering, physical sciences, or life sciences as a proxy for the technical training of employees. ${ }^{5}$ As a second type of control for innovative capability, we use a $(0,1)$ dummy variable for whether the firm is a subsidiary of a larger company. Firms that are subsidiaries of larger corporations (termed "business groups") may have access to the resources of other subsidiaries or of the corporate office that could improve the ability to innovate. ${ }^{6}$

Ratio of Annual Export Revenues to Total Firm Sales. The potential for greater sales outside of Finland may increase the incentive to innovate. Additionally, if firms with greater exports face more intense international competition, they may have stronger motivation to innovate.

Industry of Operation. Industry level factors such as technological opportunity (the potential for technological progress), appropriability of the returns to innovation, and customer demand for new products may affect the incentives of firms to innovate as well as the likelihood and extent of innovation success. We include a $(0,1)$ dummy variable for each two-digit level NACE industry in the sample (with one excluded industry per regression).

\section{RESULTS AND DISCUSSION}

\footnotetext{
${ }^{5}$ In Finland, the first degree for engineers and for most physicists and life scientists is a Master's degree requiring 5 years of study. A licentiate degree requires the same coursework as a Ph.D. (2 years beyond the Master's) but requires only one year of research following coursework (rather than 2-3 years for a Ph.D.).

${ }^{6}$ This dummy variable also controls for the fact that non-group firms have one less possible source of knowledge, since they cannot draw on a business group.
} 
Table 2, which reports descriptive statistics, shows that 67 percent of the firms in the sample succeeded in innovating. New product innovations accounted for an average of 14 percent of sales revenues for all firms, including non-innovators. On average, firms had 5.7 objectives and 5.1 knowledge sources. Table 3 reports correlation coefficients. The correlation between the breadth of innovation objectives and knowledge sources per firm is relatively high and positive: $\rho=0.39$. Not surprisingly, firms that have more innovation objectives also may have more sources of knowledge aimed at these objectives.

\section{Breadth of Objectives and Sources}

Table 4 reports regressions investigating our main proposition that greater breadth of objectives and sources is associated with greater innovation success. When the variables for breadth of objectives and sources are entered separately in the regressions, the coefficients for both variables are positive and significant at the $10 \%$ level or less in both the probit and tobit models. When objectives and sources are entered together, both are significant in the tobit regression but only sources are significant in the probit regression. Multicollinearity between objectives and sources may partly explain the latter result. Overall, these results suggest that breadth of both objectives and sources are associated with innovation success, but the probability of at least one innovation depends more strongly on breadth in sources.

We conducted two sensitivity analyses. First, we investigated whether a subset of individual objectives and knowledge sources, rather than breadth of objectives and sources, might explain our results. We created a $(0,1)$ dummy variable for each type of objective and knowledge source, to indicate whether the firm viewed that objective or source as important or very important. Then we entered these dummy variables into the regressions in table 4 in place of the original breadth variables. Given the large number of dummy variables, we ran separate regressions for objectives and sources. The results (available on request) suggest that few individual objectives or sources are strongly associated with innovation success. 
In a second sensitivity analysis, we grouped the objectives into broader categories in order to account for potential overlap among objectives. The first four objectives in table 1 were grouped into a product innovation category, the next four were grouped into a process innovation category, and the two remaining objectives were grouped into a third category of business environment innovation objectives. For each group, we assigned a binary value of 1 if at least one of the objectives in that group received a survey response of either 2 or 3 ; otherwise, the group was assigned a binary value of 0 . We then summed the binary variables for the three groups in order to obtain an indicator of breadth. We replaced the original breadth variable for objectives with the new variable and reran the original regressions reported in table 4 (column 1). This more coarse-grained measure of breadth of objectives is positive and significant in both the probit and tobit regressions, again supporting our main proposition (results available on request).

Finally, we added an interaction term between breadth of objectives and breadth of sources to the original probit regression. ${ }^{7}$ Table 5 reports the results. The marginal effect for the interaction term is positive for almost all observations, but is never statistically significant. Thus, we find no evidence of a statistically significant positive interaction effect of breadth.

\section{Diminishing Returns}

Next we investigated whether the positive effects of breadth of objectives and sources are subject to diminishing marginal returns. In order not to impose a particular functional form on the nature of any diminishing returns, we created $(0,1)$ dummy variables for each possible number of important or very important objectives and knowledge sources. For each dummy variable, a value of 1 indicated that the firm had this number of objectives or sources; otherwise, the dummy variable received a value of 0 . Thus, for objectives, we created a $(0,1)$

\footnotetext{
${ }^{7}$ Because Stata code for estimating interaction effects in tobit is not currently available (including user-generated code), we do not report tobit estimates here. We used the inteff command in Stata to compute the marginal effects and statistical significance of the interaction effect in the probit regression (see Ai and Norton 2003, Norton et al 2004).
} 
dummy variable to indicate whether a firm had one important or very important objective, another dummy variable to indicate whether a firm had two important or very important objectives, and so on. We used the same procedure for knowledge sources. We then entered each set of dummy variables into the regressions in order to ascertain at which number of objectives and sources, if any, the positive relation to innovation success diminishes.

Tables 6 and 7 report the results. For objectives, we find at best slight evidence of diminishing marginal returns. In the tobit regression, the marginal effects generally continue to increase as the number of objectives rises. The probit regression suggests a slightly greater possibility of diminishing marginal returns: the marginal effects peak at 8 objectives but are still nearly as high at the maximum possible 10 objectives. For knowledge sources, we find stronger evidence of diminishing returns. In both the probit and tobit regressions, the marginal effects rise as the number of sources increase, peak at 8 sources, and then decline. For both objectives and sources, only the coefficients at or near the peak are statistically significant, indicating their importance. ${ }^{8}$ The insignificance of the other coefficients may reflect the effect of spreading the observations over a large number of dummy variables.

Overall, the results provide some evidence of diminishing returns, particularly for knowledge sources. We also find generally increasing returns up to a relatively large number of sources and objectives, providing support for the benefits of breadth.

\section{CONCLUSION}

This study has investigated the association between breadth of technological search, in the form of innovation objectives and knowledge sources, and the innovation success of firms. To our knowledge, this is the first study to bring together theoretical arguments based on sampling models of innovation with cognitive processes that affect technological search. The sampling

\footnotetext{
${ }^{8}$ We also created dummy variables for the combined number of objectives and sources that each firm had, and entered these dummy variables into the regressions together. The tobit models showed generally increasing and statistically significant returns up to the maximum of 22 objectives and sources. The probit models also showed generally increasing returns although with less statistical significance.
} 
models and research on cognition, including dominant logic and decision biases, suggest that firms will benefit from greater breadth of innovation search. This also is the first statistical study at the firm level to assess breadth of innovation objectives and breadth of knowledge sources together, and for a relatively large set of objectives and sources. In addition, the results have the advantage that they derive from a broad sample of manufacturing industries and involve commercialized innovations.

The empirical results suggest that greater breadth of innovation objectives and knowledge sources is associated with greater innovation success at the firm level, particularly with regard to the "value" of newly commercialized innovations in terms of sales revenues. The analysis controlled for important factors that could affect innovation success such as research funding and capability, and, in a robustness analysis, showed that individual objectives and sources were not consistently significant predictors of innovation success. We also found generally increasing returns to a greater number of objectives and sources. Diminishing returns set in only at a relatively large number of sources, again supportive of the benefits of breadth. Finally, we found no evidence of a positive interaction of breadth in objectives and sources. Future research could investigate these results in other countries, preferably using samples that contain larger firms and longitudinal data.

The benefits of technological broadening identified in this study may have more general implications as well, including for exploration and exploitation (March, 1991). To the extent that breadth of objectives and sources is associated with new approaches to innovation, this study identifies another possible benefit of exploration in innovation activity. As in other activities that have highly uncertain returns, such as venture capital and oil and gas exploration, placing multiple bets may substantially improve the odds of success. This may help to counteract firms' natural cognitive tendencies to search narrowly along familiar avenues. 


\section{REFERENCES}

Ahuja G, Katila R. 2001. Technological acquisitions and the innovation performance of acquiring firms: A longitudinal study. Strategic Management Journal 22(3): 197-220.

Ahuja G, Katila R. 2004. Where do resources come from? The role of idiosyncratic situations. Strategic Management Journal 25(8-9): 887-907.

Ahuja G, Lampert CM. 2001. Entrepreneurship in the large corporation: A longitudinal study of how established firms create breakthrough inventions. Strategic Management Journal 22(67): 521-543

Ai CR, Norton EC. 2003. Interaction terms in logit and probit models. Economics Letters 80(1): 123-129

Arundel A, Paal Gvd, Soete L, MERIT (Institute), SPRINT Programme. 1995. PACE report: innovation strategies of Europe's largest industrial firms: results of the PACE survey for information sources, public research, protection of innovations and government programmes : final report. MERIT: Maastricht.

Baldwin CY, Clark, KB. 2000. Design Rules: The Power of Modularity. The MIT Press: Cambridge, MA.

Baldwin CY, Clark KB. 2003. Does code architecture mitigate free riding in the open source development model? Working paper, Harvard Business School, Boston, MA.

Bettis RA, Prahalad CK. 1995. The dominant logic - retrospective and extension. Strategic Management Journal 16(1): 5-14.

Cohen WM, Levinthal DA. 1990. Absorptive-capacity - a new perspective on learning and innovation. Administrative Science Quarterly 35(1): 128-152.

Cohen WM, Malerba, F. 2001. Is the tendency to variation a chief cause of progress? Industrial and Corporate Change 10: 587-608.

Evenson RE, Kislev Y. 1976. Stochastic-model of applied-research. Journal of Political Economy 84(2): 265-282.

Fleming L, Sorenson O. 2001. Technology as a complex adaptive system: evidence from patent data. Research Policy 30(7): 1019-1039.

Gavetti G, Levinthal D. 2000. Looking forward and looking backward: Cognitive and experiential search. Administrative Science Quarterly 45(1): 113-137.

Helfat CE. 1994. Evolutionary trajectories in petroleum firm research-and-development. Management Science 40(12): 1720-1747.

Jewkes J, Sawers D, Stillerman R. 1962. The Sources of Invention. Macmillan: London.

Katila R, Ahuja G. 2002. Something old, something new: A longitudinal study of search behavior and new project introduction. Academy of Management Journal 45: 1183-1194.

Kauffman S. 1993. The Origins of Order. Oxford University Press: New York.

Kleinknecht, A, Van Montfort K, Brouwer E. 2002. The non-trivial choice between innovation indicators. Economics of Innovation and New Technology 11(2): 109-121. 
Klevorick AK, Levin RC, Nelson RR, Winter SG. 1995. On the sources and significance of interindustry differences in technological opportunities. Research Policy 24(2): 185-205.

Kogut B, Zander U. 1992. Knowledge of the firm, combinative capabilities, and the replication of technology. Organization Science 3(3): 383-397.

Laursen K, Salter A. 2006. Open for innovation: The role of openness in explaining innovation performance among UK manufacturing firms. Strategic Management Journal 27(2): 131-150.

Leiponen A. 2000. Competencies, innovation and profitability of firms. Economics of Innovation and New Technology 9(1): 1-24.

Leiponen A. 2002. Why do firms not collaborate? Competencies, R\&D collaboration, and innovation under different technological regimes. In Innovation and Firm Performance: Econometric Explorations of Survey Data, Kleinknecht A, Mohnen P. (eds.). Palgrave: London; 253-277.

Leiponen A. 2005. Skills and innovation. International Journal of Industrial Organization 23(5-6): 303-323.

March J. 1991. Exploration and exploitation in organizational learning. Organization Science 2: 71-87.

Mol MJ, 2006. The antecedents and performance consequences of management innovation. Working paper, London Business School.

Nelson RR. 1961. Uncertainty, learning, and the economics of parallel research and development efforts. Review of Economics and Statistics 43(4): 351-364.

Podsakoff PM, Organ DW. 1986. Self-reports in organizational research: Problems and prospects. Journal of Management 12: 531-544.

Prahalad CK, Bettis RA. 1986. The dominant logic - a new linkage between diversity and performance. Strategic Management Journal 7(6): 485-501

Rosenkopf L, Nerkar A. 2001. Beyond local search: Boundary-spanning, exploration, and impact in the optical disk industry. Strategic Management Journal 22(4): 287-306.

Schumpeter JA. 1934. The Theory of Economic Development. Harvard University Press: Cambridge, MA.

Tversky A, Kahneman D. 1973. Availability - a heuristic for judging frequency and probability. Cognitive Psychology 5(2): 207-232.

Tversky A, Kahneman D. 1974. Judgment under uncertainty - heuristics and biases. Science 185(4157): 1124-1131.

Veugelers R, Cassiman B. 1999. Make and buy in innovation strategies: Evidence from Belgian manufacturing firms. Research Policy 28(1): 63-80.

Von Hippel E. 1976. The dominant role of users in the scientific instrument innovation process. Research Policy 5: 212-239. 


\section{Table 1 Innovation objectives and knowledge sources}

\begin{tabular}{|l|l|}
\hline Objectives & Mean score in sample $^{\mathbf{a}}$ \\
\hline Replace outdated products* & 1.8 \\
\hline Improve product quality* & 2.1 \\
\hline Expand product assortment* & 1.8 \\
\hline Enter new markets or increase market share* & 2.1 \\
\hline Increase flexibility of production* & 1.8 \\
\hline Reduce labor costs* & 1.6 \\
\hline Reduce use of materials* & 1.5 \\
\hline Reduce use of energy & 1.1 \\
\hline Fulfill government regulation or standards requirements & 1.3 \\
\hline Mitigate environmental damage & 1.3 \\
\hline
\end{tabular}

\begin{tabular}{|l|l|}
\hline Sources & Mean score in sample \\
\hline Own firm* & 2.2 \\
\hline Business group* & 1.7 (for 199 firms) \\
\hline Competitors* & 1.6 \\
\hline Customers* & 2.3 \\
\hline Consulting firms & 0.9 \\
\hline Suppliers of equipment, materials, components, or software* & 1.5 \\
\hline Universities & 1.3 \\
\hline Public or private non-profit research institutes & 1.0 \\
\hline Patents & 0.8 \\
\hline Conferences, scientific/trade publications & 1.4 \\
\hline Databases (e.g. Internet) & 0.8 \\
\hline Trade fairs, exhibitions & 1.5 \\
\hline
\end{tabular}

* Most or somewhat important objectives and sources based on average survey responses (raw mean score above 1.50, mean binary value above 0.50 )

a Rounded to the nearest tenth 
Table 2 Descriptive Statistics $(\mathrm{N}=339)$

\author{
$\underline{\text { Variable }}$ \\ Employees \\ Log \# employees \\ Business group $(0,1)$ \\ Export share of revenues \\ $\%$ of employees $\mathrm{w} / \mathrm{Ph} . \mathrm{D}$ \\ $\%$ of employees w/college technical/science degree \\ Innovation success $(0,1)$ \\ Percent of product sales revenues from innovation \\ Log R\&D expenditures \\ Objectives \\ Sources
}

\begin{tabular}{|c|c|c|c|}
\hline$\frac{\text { Mean }}{317.634}$ & $68 \frac{\text { Std. Dev. }}{689.009}$ & $\frac{\text { Minimum }}{10}$ & $\frac{\text { Maximum }}{6615}$ \\
\hline 4.771 & 1.378 & 2.303 & 8.797 \\
\hline .593 & .4920 & 0 & 1 \\
\hline .341 & .323 & 0 & 1 \\
\hline .373 & 1.341 & 0 & 13.671 \\
\hline 10.623 & 10.709 & 0 & 56.860 \\
\hline .673 & .470 & 0 & 1 \\
\hline 14.274 & 21.854 & 0 & 100 \\
\hline 6.3003 & 2.738 & 0 & 12.612 \\
\hline 5.658 & 2.298 & 0 & 10 \\
\hline 5.083 & 2.159 & 0 & 12 \\
\hline
\end{tabular}

\section{Table 3 Correlation Coefficients ( $N=339)$}

1. Log \# employees

2. Business group

3. Export share of revenues

4. $\%$ of employees $\mathrm{w} / \mathrm{Ph} . \mathrm{D}$

5. $\%$ of employees w/college technical/science degree

6. Innovation success $(0,1)$

7. Percent of product sales revenues from innovation

8. Log R\&D expenditures

9. Objectives

10. Sources

$1 \quad 2 \quad 3$

1

$0.4966 * 1$

$0.2877 * 0.2271 * \quad 1$

$0.2790 * 0.1640 * 0.1645 * 1$

$\begin{array}{lllll}0.1768 * & 0.0864 & 0.1817 * & 0.4564 * 1\end{array}$

$0.6006 * 0.3985 * 0.3302 * 0.3647 * 0.2987 * 1$

$\begin{array}{lllllll}0.0051 & 0.1209 & 0.2014 * & 0.2094 * & 0.3031 * & 0.2982 * & 1\end{array}$

$\begin{array}{llllllll}0.0568 & 0.1194 & 0.0221 & 0.115 & 0.2852 * & 0.2224 * & 0.4046 * & 1\end{array}$

$\begin{array}{lllllllll}0.1255 & -0.0425 & -0.0498 & 0.1096 & 0.1778 * & 0.0902 & -0.1672 * & -0.0677 & 1\end{array}$

$\begin{array}{lllllllll}0.3461 * & 0.2378 * & 0.1344 & 0.2542 * & 0.2215 * & 0.2663 * & 0.0576 & 0.1515 * & 0.3868 *\end{array}$

* denotes significance at the $1 \%$ level 
Table 4 Breadth of innovation objectives and knowledge sources $(\mathrm{N}=339)$

\begin{tabular}{|c|c|c|c|c|c|c|c|c|c|}
\hline \multirow[b]{2}{*}{ Variable } & \multicolumn{9}{|c|}{ Innovation success $(0,1)$ (probit maximum likelihood) } \\
\hline & $\begin{array}{l}\text { Coefficient } \\
\text { (Std Error) }\end{array}$ & $\begin{array}{l}\text { Signif. } \\
\text { Level }\end{array}$ & ME & $\begin{array}{l}\text { Coefficient } \\
\text { (Std Error) }\end{array}$ & $\begin{array}{l}\text { Signif. } \\
\text { Level }\end{array}$ & ME & $\begin{array}{l}\text { Coefficient } \\
\text { (Std Error) }\end{array}$ & $\begin{array}{l}\text { Signif. } \\
\text { Level }\end{array}$ & ME \\
\hline constant & $-1.790(.555)$ & .001 & -.604 & $-1.640(.525)$ & .002 & -.552 & $-1.772(.555)$ & .001 & -.596 \\
\hline $\log \#$ employees & $.209(.085)$ & .014 & .071 & $.158(.087)$ & .070 & .053 & $.161(.088)$ & .066 & .054 \\
\hline business group $(0,1)$ & $-.063(.191)$ & .741 & -.021 & $-.117(.192)$ & .544 & -.039 & $-.102(.193)$ & .596 & -.034 \\
\hline export share of revenues & $.007(.294)$ & 982 & .002 & $-.018(.296)$ & .953 & -.006 & $-.011(.296)$ & .969 & -.004 \\
\hline $\log R \& D$ expenditures & $.108(.040)$ & .007 & .037 & $.114(.041)$ & .005 & .038 & $.111(.041)$ & .006 & .037 \\
\hline$\%$ employees w/Ph.D. & $.064(0.102)$ & .527 & .022 & $.025(0.097)$ & .794 & .009 & $.035(0.100)$ & .728 & .012 \\
\hline $\begin{array}{l}\% \text { employees w/college } \\
\text { technical/science degree }\end{array}$ & $.010(0.010)$ & .319 & .004 & $.008(0.011)$ & 448 & .003 & $.009(0.011)$ & 405 & .003 \\
\hline objectives & $.070(.036)$ & .051 & .024 & & & & $.030(.040)$ & .452 & .010 \\
\hline sources & & & & $.119(.042)$ & .005 & .040 & $.103(.047)$ & .029 & .035 \\
\hline industry dummies & \multicolumn{3}{|c|}{ Included } & \multicolumn{3}{|c|}{ Included } & \multicolumn{3}{|c|}{ Included } \\
\hline log likelihood & \multicolumn{2}{|l|}{-173.64} & & \multicolumn{2}{|l|}{-171.50} & \multicolumn{4}{|c|}{-171.21} \\
\hline chi squared (pr>chi sq) & 81.44 & \multirow{2}{*}{\multicolumn{2}{|c|}{$(.00)$}} & \multicolumn{3}{|c|}{$85.73(.00)$} & \multicolumn{3}{|c|}{$86.3 \quad(.00)$} \\
\hline Pseudo $\mathrm{R}^{2}$ & $19.00 \%$ & & & $20.00 \%$ & & & $20.13 \%$ & & \\
\hline
\end{tabular}

\section{Percent of product sales revenues from innovation (tobit maximum likelihood)}

\begin{tabular}{|c|c|c|c|c|c|c|c|c|c|}
\hline Variable & $\begin{array}{l}\text { Coefficient } \\
\text { (Std Error) }\end{array}$ & $\begin{array}{l}\text { Signif. } \\
\text { Level }\end{array}$ & $\mathrm{ME}$ & $\begin{array}{l}\text { Coefficient } \\
\text { (Std Error) }\end{array}$ & $\begin{array}{l}\text { Signif. } \\
\text { Level }\end{array}$ & ME & $\begin{array}{l}\text { Coefficient } \\
\text { (Std Error) }\end{array}$ & $\begin{array}{r}\text { Signif. } \\
\text { Level } \\
\end{array}$ & $\mathrm{ME}$ \\
\hline constant & $-38.265(11.610)$ & 0.001 & -22.418 & $-29.680(11.082)$ & .008 & -17.301 & $-39.179(11.586)$ & .001 & -22.925 \\
\hline log \# employees & $1.577(1.666)$ & 0.345 & .924 & 1.255 (1.707) & .463 & .732 & $1.027(1.683)$ & .542 & .601 \\
\hline business group $(0,1)$ & $-3.498(3.829)$ & 0.362 & -2.050 & $-6.263(3.855)$ & .105 & -3.651 & $-4.448(3.849)$ & .249 & -2.603 \\
\hline $\begin{array}{l}\text { export sha } \\
\text { revenues }\end{array}$ & $6.902(5.585)$ & 0.217 & 4.044 & $4.744(5.658)$ & 402 & 2.766 & $6.005(5.588)$ & . 283 & 3.514 \\
\hline expenditures & $2.944(.878)$ & 0.001 & 1.725 & $3.160(0.888)$ & .000 & 1.842 & $2.972(.876)$ & .001 & 1.739 \\
\hline$\%$ employees w/Ph.D & $3.607(1.259)$ & 0.004 & 2.113 & $3.031(1.277)$ & .018 & 1.767 & $3.244(1.264)$ & .011 & 1.898 \\
\hline $\begin{array}{l}\text { \% employees college } \\
\text { technical/science } \\
\text { degree }\end{array}$ & .454( & 0.019 & .266 & $.362(.193)$ & .063 & 211 & .439 & .023 & .257 \\
\hline objectives & $2.721(.738)$ & 0.000 & 1.594 & & & & $2.138(.791)$ & .007 & 1.251 \\
\hline sources & & & & $2.594(0.812)$ & .002 & 1.512 & $1.712(.860)$ & .047 & 1.002 \\
\hline industry dummies & Included & & & Included & & & Included & & \\
\hline log likelihood & -1046.59 & & & -1048.22 & & & -1044.60 & & \\
\hline$\sigma$ & $25.81(1.35)$ & 00 & & $26.10(1.37)$ & .00 & & $25.68(1.35)$ & .00 & \\
\hline
\end{tabular}

Note: the ME column contains marginal effects of the coefficients calculated at means. For binary variables, the marginal effect measures change in probability when the binary variable is turned on. 
Table 5 Diminishing returns to innovation objectives $(\mathrm{N}=339)$

\begin{tabular}{|c|c|c|c|c|c|c|}
\hline \multirow[b]{2}{*}{ Variable } & \multicolumn{3}{|c|}{$\begin{array}{c}\text { Innovation success }(0,1) \\
\text { (probit ML) }\end{array}$} & \multicolumn{3}{|c|}{$\begin{array}{l}\text { Percent of product sales revenues } \\
\text { from innovation (tobit ML) }\end{array}$} \\
\hline & $\begin{array}{l}\text { Coefficient } \\
\text { (Std Error) }\end{array}$ & $\begin{array}{l}\text { gnifican } \\
\text { Level }\end{array}$ & ME & $\begin{array}{l}\text { Coefficient } \\
\text { (Std Error) }\end{array}$ & $\begin{array}{c}\text { Significan } \\
\text { Level }\end{array}$ & $\mathrm{ME}$ \\
\hline constant & $-2.115(.757)$ & .005 & -.709 & $-43.566(17.707)$ & .014 & -25.571 \\
\hline $\log$ \# employees & $.226(.087)$ & .010 & .076 & $1.646(1.675)$ & .327 & .966 \\
\hline business group $(0,1)$ & $-.089(.196)$ & .651 & -.030 & $-2.899(3.826)$ & .449 & -1.702 \\
\hline export share of revenues & $-.052(.301)$ & .863 & -.017 & $6.284(5.567)$ & .260 & 3.689 \\
\hline $\log R \& D$ expenditures & $.103(.041)$ & .013 & .035 & $2.902(0.878)$ & .001 & 1.703 \\
\hline$\%$ employees w/Ph.D. & $.077(.109)$ & .477 & .026 & $3.538(1.261)$ & .005 & 2.076 \\
\hline $\begin{array}{l}\% \text { employees college } \\
\text { technical/science degree } \\
\text { number of objectives: }\end{array}$ & $.010(.011)$ & .351 & .003 & $0.471(0.193)$ & .015 & .277 \\
\hline one & $.519(.867)$ & .549 & .144 & $23.165(20.510)$ & .260 & 13.597 \\
\hline two & $.610(.653)$ & .350 & .167 & $7.905(15.452)$ & .609 & 4.640 \\
\hline three & $.339(.608)$ & .577 & .103 & $17.619(14.886)$ & .238 & 10.341 \\
\hline four & $.531(.597)$ & .373 & .155 & $11.901(14.384)$ & .409 & 6.985 \\
\hline five & $.672(.598)$ & .261 & .190 & $21.069(14.439)$ & .146 & 12.367 \\
\hline $\operatorname{six}$ & $.677(.596)$ & .256 & .193 & $19.924(14.336)$ & .166 & 11.695 \\
\hline seven & $.903(.611)$ & .140 & .236 & $23.542(14.606)$ & .108 & 13.818 \\
\hline eight & $1.149(.632)$ & .069 & .264 & $28.708(14.784)$ & .053 & 16.850 \\
\hline nine & $.405(.635)$ & .524 & .120 & 24.964 (14.969) & .096 & 14.653 \\
\hline ten & $1.098(.685)$ & .109 & .245 & $37.103(15.414)$ & .017 & 21.778 \\
\hline industry dummies & Included & & & Included & & \\
\hline log likelihood & -170.90 & & & -1044.35 & & \\
\hline chi squared $\left(\right.$ pr $\left.>\mathrm{Chi}^{2}\right)$ & 86.94 & $(.00$ & & 123.41 & & \\
\hline Pseudo $\mathrm{R}^{2}$ & $20.30 \%$ & & & & & \\
\hline$\sigma$ & & & & $25.57(1.34)$ & & $00)$ \\
\hline
\end{tabular}

Note: The ME column displays marginal effects at means. 
Table 6 Diminishing returns to knowledge sources ( $\mathrm{N}=339)$

\begin{tabular}{|c|c|c|c|c|c|c|}
\hline \multirow[b]{2}{*}{ Variable } & \multicolumn{3}{|c|}{$\begin{array}{c}\text { Innovation success }(0,1) \\
\text { (probit ML) }\end{array}$} & \multicolumn{3}{|c|}{$\begin{array}{c}\text { Percent of product sales revenues from } \\
\text { innovation (tobit ML) }\end{array}$} \\
\hline & $\begin{array}{l}\text { Coefficient } \\
\text { (Std Error) }\end{array}$ & $\begin{array}{l}\text { Significance } \\
\text { Level }\end{array}$ & ME & $\begin{array}{l}\text { Coefficient } \\
\text { (Std Error) }\end{array}$ & $\begin{array}{c}\text { Significance } \\
\text { Level }\end{array}$ & $\mathrm{ME}$ \\
\hline constant & $-1.465(.919)$ & .111 & -.479 & $-46.871(23.521)$ & .047 & -27.312 \\
\hline log \# employees & $.169(.090)$ & .061 & .055 & $1.351(1.708)$ & .430 & .787 \\
\hline business group $(0,1)$ & $-.115(.198)$ & .562 & -.037 & $-6.854(3.833)$ & .075 & -3.994 \\
\hline export share of revenues & $-.048(.307)$ & .877 & -.016 & $5.905(5.666)$ & .298 & 3.441 \\
\hline $\log \mathrm{R} \& \mathrm{D}$ expenditures & $.122(.043)$ & .005 & .040 & $3.172(.900)$ & .000 & 1.848 \\
\hline$\%$ employees w/Ph.D. & $3.907(10.173)$ & .701 & .013 & $3.157(1.261$ & .013 & 1.840 \\
\hline $\begin{array}{l}\% \text { employees college } \\
\text { technical/science degree } \\
\text { number of sources: }\end{array}$ & $.687(.073)$ & .522 & .002 & $.395(.192)$ & .041 & .230 \\
\hline one & $-.484(.903)$ & .592 & -.177 & $7.934(24.213)$ & .743 & 4.623 \\
\hline two & $.033(.791)$ & .967 & .011 & $19.488(21.084)$ & .356 & 11.356 \\
\hline three & $.030(.776)$ & .969 & .001 & $24.589(20.577)$ & .233 & 14.328 \\
\hline four & $.282(.779)$ & .718 & .086 & $29.155(20.583)$ & .158 & 16.988 \\
\hline five & $.231(.770)$ & .764 & .072 & $25.773(20.402)$ & .207 & 15.018 \\
\hline $\operatorname{six}$ & $.218(.781)$ & .781 & .068 & $29.986(20.439)$ & .143 & 17.472 \\
\hline seven & $.766(.795)$ & .336 & .201 & $34.825(20.510)$ & .091 & 20.293 \\
\hline eight & $1.789(.908)$ & .049 & .296 & $46.960(20.791)$ & .025 & 27.363 \\
\hline nine & $.264(.896)$ & .768 & .079 & $23.295(21.855)$ & .287 & 13.574 \\
\hline ten or more & $-.073(.933)$ & .938 & -.024 & $30.679(22.161)$ & .167 & 17.876 \\
\hline industry dummies & Included & & & Included & & \\
\hline log likelihood & -164.94 & & & -1042.82 & & \\
\hline chi squared $\left(\mathrm{pr}>\mathrm{Chi}^{2}\right)$ & 98.86 & $(.000)$ & & 126.47 & $(.000)$ & \\
\hline Pseudo $\mathrm{R}^{2}$ & $23.10 \%$ & & & & & \\
\hline$\sigma$ & & & & $25.66(1.34)$ & $(.000)$ & \\
\hline
\end{tabular}


Table 7 Interaction of breadth of innovation objectives and knowledge sources $(\mathrm{N}=339)$

\begin{tabular}{|c|c|c|c|}
\hline \multirow{2}{*}{ Variable } & \multicolumn{3}{|c|}{$\begin{array}{l}\text { Innovation success }(0,1) \\
\text { (probit ML) }\end{array}$} \\
\hline & $\begin{array}{l}\text { Coefficient } \\
\text { (Std Error) }\end{array}$ & $\begin{array}{c}\text { Significance } \\
\text { Level }\end{array}$ & $\mathrm{ME}$ \\
\hline constant & $-1.589(.664)$ & .017 & \\
\hline log \# employees & $.159(.088)$ & .071 & .053 \\
\hline business group $(0,1)$ & $-.097(.194)$ & .618 & -.032 \\
\hline export share of revenues & $-.017(.297)$ & .955 & -.006 \\
\hline log R\&D expenditures & $.113(.041)$ & .006 & .038 \\
\hline$\%$ employees w/Ph.D. & $.044(.104)$ & 669 & 1.494 \\
\hline $\begin{array}{l}\% \text { employees college } \\
\text { technical/science degree }\end{array}$ & $.009(.011)$ & .419 & .287 \\
\hline objectives & $-.004(.080)$ & .956 & -.001 \\
\hline sources & $.060(.097)$ & .538 & .020 \\
\hline objectives X sources & $.008(*)$ & $*$ & $*$ \\
\hline industry dummies & Included & & \\
\hline log likelihood & -171.09 & & \\
\hline chi squared $\left(\mathrm{pr}>\mathrm{Chi}^{2}\right)$ & 86.55 & $(.000)$ & \\
\hline Pseudo $\mathrm{R}^{2}$ & $20.00 \%$ & & \\
\hline
\end{tabular}

* Marginal effect is positive but small for most observations, with a maximum of less than .00425 . The interaction effect lacks statistical significance for all observations. 